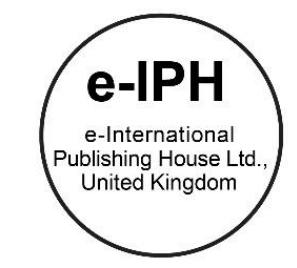

\title{
Factors Influencing Students' Performance in the First Computer Programming Course Taught Using Blended Learning Approach
}

\author{
Zulaile Mabni', Noratikah Shamsudin1, Sharifah Aliman'1, Rosmah Abdul Latif² \\ ${ }^{1}$ Faculty of Computer and Mathematical Sciences, \\ Universiti Teknologi MARA,40450 Shah Alam, Selangor, Malaysia \\ ${ }^{2}$ Faculty of Computer and Mathematical Sciences, \\ Universiti Teknologi MARA, Seremban Campus, 70300 Seremban, Negeri Sembilan, Malaysia
}

zulaile@tmsk.uitm.edu.my,atikah@tmsk.uitm.edu.my,sharifahali@tmsk.uitm.edu.my,rose@tmsk.uitm.edu.my

Tel: +60355211173

\begin{abstract}
This study investigates the factors that influence the students' performance in the first computer programming course taught using the blended learning approach. A blended learning model proposed by Hadjerrouit was adapted, which consists of conceptualization, construction, and dialogue phases. The objective of this study is to identify which phase in the adapted blended learning model has an influence on the performance of the students. A cross-sectional population study with simple random sampling was conducted at Universiti Teknologi MARA (UiTM). Stepwise multiple linear regression revealed that only the construction phase of the blended learning model was significant towards students' performance.
\end{abstract}

Keywords: Blended Learning; Face-to-Face Learning; Programming; Online Learning

eISSN: 2398-4287@ 2020. The Authors. Published for AMER ABRA CE-Bs by e-International Publishing House, Ltd., UK. This is an open access article under the CC BYNC-ND license (http://creativecommons.org/licenses/by-nc-nd/4.0/). Peer-review under responsibility of AMER (Association of Malaysian Environment-Behaviour Researchers), ABRA (Association of Behavioural Researchers on Asians) and cE-Bs (Centre for Environment-Behaviour Studies), Faculty of Architecture, Planning \& Surveying, Universiti Teknologi MARA, Malaysia. DOI: https://doi.org/10.21834/ebpj.v5iSI3.2559

\subsection{Introduction}

Several research studies have shown that learning computer programming requires students to have problem-solving and analytical thinking skills (Ismail et al., 2010; Bati et al., 2014). However, the students who are pursuing computer programming courses are lacking problem-solving skills (Shamsuddin et al., 2018). Many students found that learning programming is difficult and challenging. Teaching programming is a challenge since the failure and dropout rate is high in the introductory programming course (Bati et al., 2014). One of the pervasive approaches to tackle the learning problem in the introductory programming course is the blended learning approach ( Albrecht et al., 2018; Alammary, 2019). Blended learning is a combination of face-to-face learning and online learning (Hadjerrouit, 2008; Haron et al., 2012; Ramakrisnan et al., 2012). This study used a case study approach to investigate the factors that influence the students' performance in the first computer programming course taught using a blended learning approach at Faculty of Computer and Mathematical Sciences, Universiti Teknologi MARA (UiTM).

In this study, the approach for teaching is a combination of both traditional face-to-face learning and online learning. The platform used for teaching and learning is The Learning Management System (LMS) of UiTM. LMS is an application software designed to

eISSN: 2398-4287C 2020. The Authors. Published for AMER ABRA cE-Bs by e-International Publishing House, Ltd., UK. This is an open access article under the CC BYNC-ND license (http://creativecommons.org/licenses/by-nc-nd/4.0/). Peer-review under responsibility of AMER (Association of Malaysian Environment-Behaviour Researchers), ABRA (Association of Behavioural Researchers on Asians) and cE-Bs (Centre for Environment-Behaviour Studies), Faculty of Architecture, Planning \& Surveying, Universiti Teknologi MARA, Malaysia. DOI: https://doi.org/10.21834/ebpj.v5iSI3.2559 
facilitate learning and course work (Salem \& Salem, 2015; Kim, 2017; Mestan, 2019). The LMS used in this study is called i-Learn, which facilitate e-learning in UiTM and acts as a platform that supports the teaching and learning process in UiTM. The $i$-Learn system consists of many applications such as content management systems, student records, courses information management systems, forums, internal communication, and online evaluation system (Za'ba et al., 2012). For the blended learning approach, the combination of e-learning and face-to-face learningis used to teach students. The e-learning materials consist of online activities such as online lecture notes, programming examples, programming solutions, past exams, quizzes, evaluation, discussion, and group collaboration. In addition to that, students' performance is evaluated based on their final examination scores.

This study used a case study approach to apply a three-stage model or learning cycle initially proposed by Mayes and Fowler (1999) and later adapted by Hadjerrouit (2008). This model consists of three phases, namely: conceptualization, construction, and dialogue phases. The learning cycle starts with the conceptualization phase, and then followed by the construction phase, and finally the dialogue phase. The conceptualization phase involves the interaction between the lecturer's knowledge and the students' preexisting framework. Next, the construction phase involves students in task-based activities, where, the new knowledge or concepts are constructed. Lastly, during the dialogue phase, the concepts of the subject matter and the construction of new concepts are tested by both students and lecturers through conversations. The three uses of the Web (Roberts, 2003) and three uses of blended learning (Hadjerrouit, 2008) are adapted from the Mayes and Fowler's model, as shown in Fig.1.

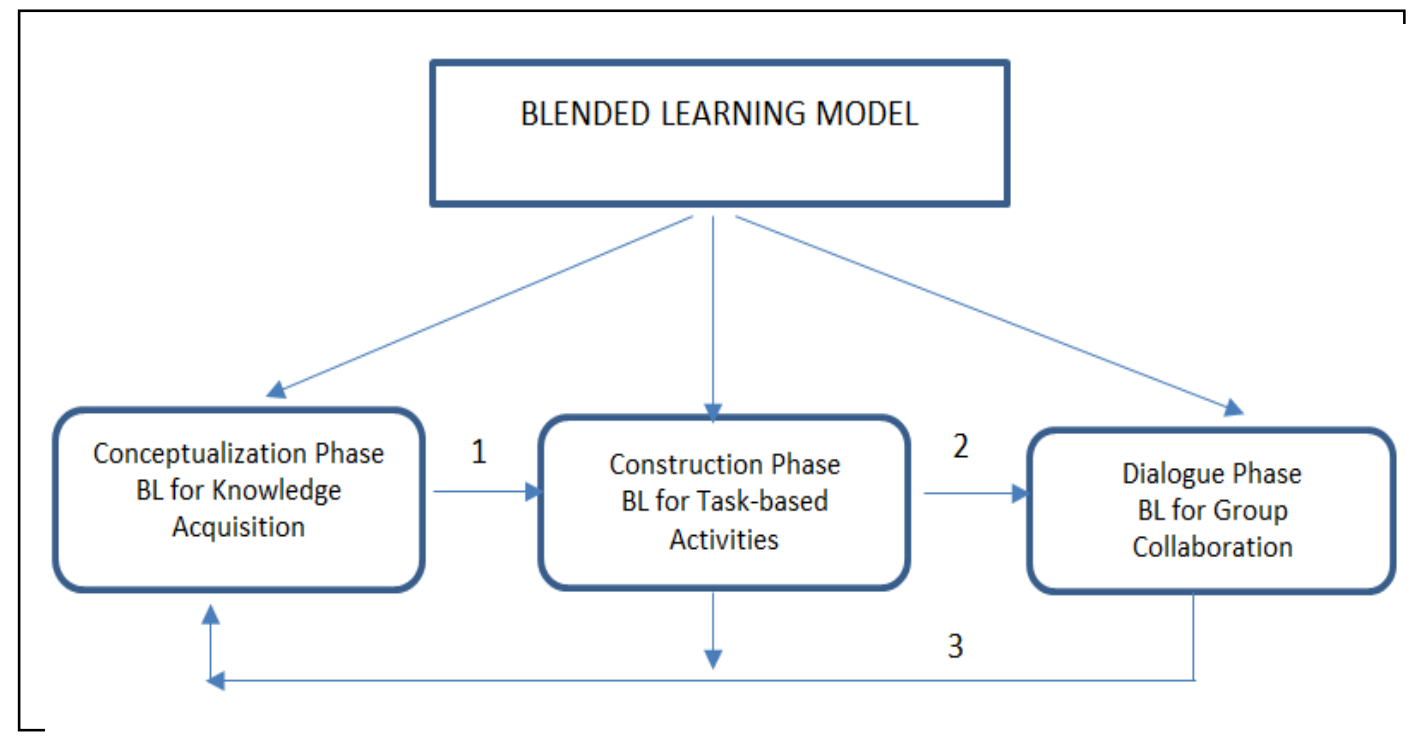

Fig. 1 shows the blending learning approach at three different phases, as follows:

- The conceptualization phase

At this level, the learning model combines face-to-face learning with online materials related to concepts of the subject matter. In this phase, the student is acquiring knowledge.

- The construction phase

At this level, the learning model combines learning activities with online task-based activities. In this phase, the learner is involved in constructing new knowledge.

- The dialogue phase

At this level, the learning model combines face-to-face dialogue with online discussion and group collaboration.

This study aims to identify which phase in the adapted blended learning model has an influence on the performance of the students in their first computer programming course. We examined the performance of the students based on their satisfaction on the conceptualization, the construction, and the dialogue phases between lecturers and students of the blended learning approach.

\subsection{Related Work}

Several studies have conducted courses using a blended learning method as an educational delivery method in improving students' learning outcomes (Twigg, 2004; Lim \& Morris, 2009). The Pew Foundation in the United States has funded research on using blended learning, found that among thirty educational institutions that participated, twenty out of them reported their learning outcome improved. In contrast, eighteen of the participating institutions reported that student drop-failure-withdrawal (DFW) rates have 
declined (Twigg, 2004). The study also said that redesigning courses as blended learning had improved students' performance. These students have achieved better grades, knowledge, and understanding of the course concepts.

A related study on blended learning style has compared the advantages in terms of students' participation between blended learning style and pure virtual e-learning style (Dodero et al., 2003). The study indicates that in traditional classroom teaching, information technologies can improve students' participation. However, in a completely virtual classroom, these technologies do not enhance their involvement.

Another advantage of blended learning is that students can flexibly access the learning materials. Students can access the online course whenever and wherever they want if they can access the Internet and without going to classes. Thus, according to Sharpe et al.(2006), blended learning enables students to have the autonomy to control their education and gives powers to research. Blended learning also enhances students' ability to catch up on their courses based on their preferred time and place (Owston et al., 2008).

Poon (2013) stated that the success of developing blended learning depends on the suitability of the resources and courses. Besides, the support from the senior management of the university also contributed to the success. According to Deperlioglu and Kose (2013), combining online learning and face-to-face learning can enhance learning and optimize seat time. They conducted a study on using blended e-learning model in "Data Structures and Algorithms" course offered at the Afyon Kocatepe University in Turkey. The findings showed that students had experienced more effective and efficient learning in the realized blended learning as compared to traditional face-to-face learning.

Another study demonstrated that the key to the success of a blended learning approach is by redesigning the blended courses for active and collaborative learning experiences which enable students to be responsible for their learning (Vaughan, 2014). Students can also validate their understanding through discussion and debate with their peers. A recent study in mainstream education in New Zealand has proposed that digital information literacybe embedded into the blended learning course for enhancing the blended learning experience (Schwenger, 2016). This study found that this approach can address students' potential learning challenges related to digital information literacy and encourage independent learning.

A recent study has investigated the effects of blended learning approach on the performance of students in the first computer programming course at Faculty of Computer and Mathematical Sciences, Universiti Teknologi MARA (UiTM) (Mabni et al., 2018). The study has compared the performance of the students taught using a blended learning approach with the performance of the students taught using a traditional face-to-face learning approach. The finding of this study indicated that the blended learning approach gave a positive impact on students who have prior programming background towards their performance in their first computer programming course.

\subsection{Research Methodology}

This study used a case study approach to investigate the effect of applying the blended learning approach on the students' performance in the first programming course. A cross-sectional study was conducted in the Faculty of Computer and Mathematical Sciences, UiTM.

\subsection{Target Sample}

The target population was the undergraduate students who enrolled for the first $\mathrm{C}++$ programming course named Fundamentals of Computer Problem Solving in semester September 2016 until January 2017. By using stratified sampling, the target sample comprised of a group of undergraduate students with a total of 35 students taught using the blended learning approach. The limitation of this study is, the samplingsize is small, thus the findings of this study cannot be generalized to the whole population.

\subsection{Data Collection}

Data were collected from 35 students through an email questionnaire using Google form. All 35 students had responded to the surveys. The surveys comprised of three sections. Section A asking about demographic factors such as student's profiles, and details on program and course enrolled. Section B evaluating on the online resources and Section $\mathrm{C}$ getting feedback on the phases of the blended learning model. As for the blended learning section, the instrument used the blended learning model that consists of 3 main phases which are conceptualization, construction, and dialogue (Hadjerrouit, 2008). In addition to the survey questionnaires, the final exam grades achieved by the students were collected to identify their performance in the subject taught.

\subsection{Method Analysis}

The data were analyzed using IBM SPSS Version 21 program. All data were summarized using descriptive statistics. In contrast, stepwise multiple linear regressions were used to predict the undergraduates' performance based on the conceptualization, construction, and the dialogue phases implemented in the blended learning approach.

\subsection{Result and Analysis}




\subsection{Reliability Testing for Instrument}

The reliability testing on the instrument used in the study is as follows:

Table 1. The reliability testing of the instrument used

\begin{tabular}{lll}
\hline Component & No. of item & Cronbach's Alpha \\
\hline Overall Item & 36 & 0.917 \\
Online Resource & 11 & 0.852 \\
Conceptualization & 8 & 0.912 \\
Construction & 10 & 0.891 \\
Dialogue & 7 & 0.762 \\
\hline
\end{tabular}

Based on Table 1 shown above, the overall Cronbach's alpha (Reynaldo \& Santos, 1999) for the instrument is greater than 0.7 which indicated that the instrument is reliable since all the items asked in the instrument represent each property in blended learning.

\subsection{Descriptive Statistics}

Table 2 below shows the skewness and kurtosis for the students' final examination marks.

Table 2. Skewness and kurtosis for students' final examination marks

\begin{tabular}{lllll}
\multicolumn{5}{c}{ Table 2. Skewness and kurtosis for students' final examination marks } \\
\hline Dependent variable & Mean & Std. Deviation & Skewness & Kurtosis \\
\hline Undergraduates' examination marks & 75.886 & 10.7040 & -0.252 & -0.074 \\
\hline
\end{tabular}

Based on Table 2, the skewness and kurtosis for students' final examination marks are in the range between \pm 2 and \pm 3 . Therefore, this indicates that the data for undergraduates' final examination marks is not highly skewed and concluded as normally distributed.

\subsection{Model Adequacy Checking for Stepwise Linear Regression}
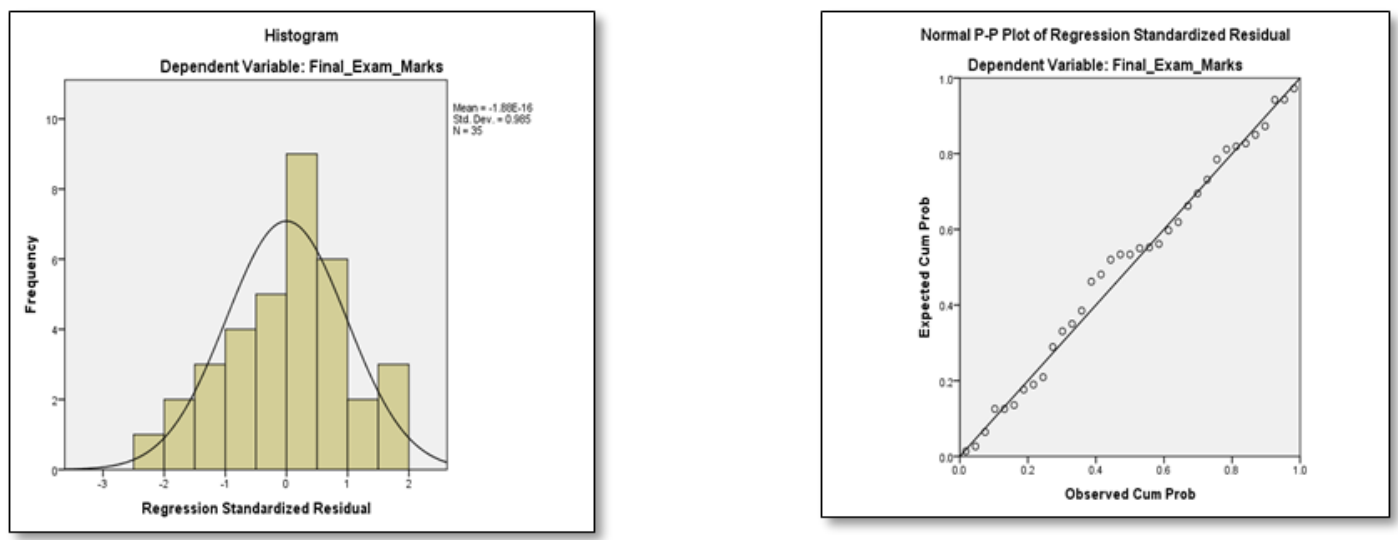

Fig 2: Histogram and Normal P-P Plot of the error term

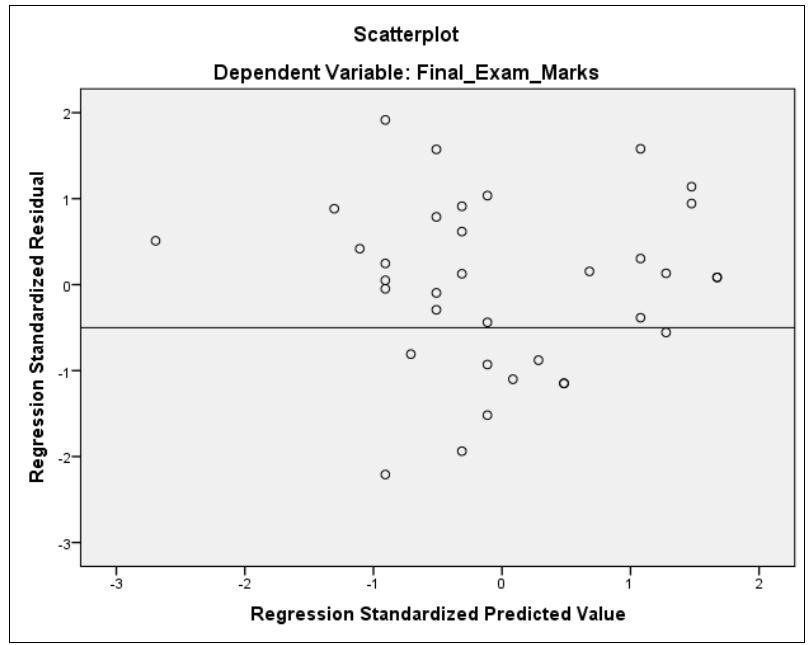

Fig. 3: The scatter plot of the error variance 
The model adequacy checking was performed using multiple linear regression(Kutner et. al.2005) with the Enter method before proceeding with the stepwise regression analysis to remove the in significant factor. Since the measurement for conceptualization, construction, and dialogue of blended learning is in ordinal, linearity assumption does not have to be tested.

Fig. 2 indicates that the error terms are normally distributed since there is no obvious skewed pattern identified from the histograms. Meanwhile, the normal p-p plots showed no indication of outlier presence since the dots are plotted along the straight line.

The error variance is constant, as shown in Fig. 3. It is proven since there is no systematic pattern shown in the scatter plot, we can conclude that homogeneity of variance is satisfied.

Table 3 shows the presence of multicollinearity based on the Enter method. The value of tolerance and VIF for each of the blended learning properties is greater than 0.10 and below 10. Therefore, this indicates that there is no multicollinearity problem exists in the data.

\begin{tabular}{lll}
\multirow{2}{*}{ Table 3. The presence of multicollinearity based on the Enter method } \\
\cline { 2 - 3 } & Undergraduates' Final Marks & \multicolumn{3}{l}{ Collinearity Statistics } \\
\cline { 2 - 3 } & Tolerance & VIF \\
\hline Concept & 0.650 & 1.539 \\
Construct & 0.677 & 1.478 \\
Dialogue & 0.868 & 1.153 \\
\hline
\end{tabular}

\subsection{Multiple Linear Regression using Stepwise Method}

Table 4 shows the stepwise regression analysis for the students' final examination marks.

Table 4. Stepwise regression analysis for undergraduates' final examination marks

\begin{tabular}{llllll}
\hline Model & Coefficient & $\mathrm{t}$ & Sig. & Tolerance & VIF \\
\hline Constant & 45.027 & 3.103 & .004 & & \\
Construct & 7.423 & 2.141 & .040 & 1.000 & 1.000 \\
\hline a. Dependent Variable: Students' final examination marks & & & \\
\hline
\end{tabular}

From the stepwise regression analysis in Table 4 above, we can estimate a multiple linear regression equation as given in equation (1):

$$
\text { Students' Final Performance } \quad=45.027+7.423 \text { (Construct) }
$$

Thus, we could see that only the construction phase of the blended learning is significant towards the enhancement of students' final examination marks. The positive sign of the construct's coefficient indicates that the higher satisfaction on the construction phase of the blended learning model will contribute to higher performance in students' final examination marks.

\subsection{Conclusion}

The findings showed that the construction phase of the blended learning model is the factor that needs to be seriously taken into consideration since it is significant towards the enhancement of students' performance. Therefore, the current blended learning approach needs to focus on constructing the blended learning for computer programming syllabus effectively to improve the students' satisfaction level. On the other hand, the conceptualization phase of blended learning and the dialogue phase between lecturers and students need to be improved so that it may contribute to the students' performance in the future ahead. Since this is only a case study with a small sampling size, thus, the findings can be used for Universiti Teknologi MARA (UiTM) and cannot be generalized to the whole population. Large sample sizes are needed for further analysis so that it can represent the entire undergraduates' population experiencing blended learning in Malaysia.

\section{Acknowledgements}

We wish to acknowledge the support of Universiti Teknologi MARA (UiTM) under the ARAS Grant No: 600-IRMI/DANA 5/3/ARAS (0013/2016).

\section{References}

Alammary, A. (2019). Blended learning models for introductory programming courses: A systematic review. PLoS ONE 14(9).

Albrecht, E., Gumz, F., Grabowski, J. (2018). Experiences in introducing blended learning in an introductory programming course. Proceedings of the 3rd European Conference of Software Engineering Education, ACM,93-101.

Bati, T. B., Gelderblom, H., \& Biljon, J. V. (2014). A blended learning approach for teaching computer programming: Design for large classes in Sub-Saharan Africa. Computer Science Education, 24(1), 71-99. 
Deperlioglu, O., \& Kose, U. (2013). The effectiveness and experiences of blended learning approaches to computer programming education. Computer Applications in Engineering Education, 21(2), 328-342, June 2013

Dodero, J.M., Fernández, C., \& Sanz, D. (2003). An experience on students' participation in blended vs. online styles of learning. SIGCSE Bulletin, 35(4), 39-42.

Reynaldo, J. \& Santos, A. (1999). Cronbach's Alpha: A tool for assessing the reliability of scales. Journal of Extension, 37(2).

Hadjerrouit, S. (2008). Towards a blended learning model for teaching and learning computer programming: A case study. Informatics in Education, 2008, 7(2), 181210.

Haron, H., Abbas, W. F., \& Abd Rahman, N. A. (2012). The adoption of blended learning among Malaysian academicians. Procedia - Social Science and Behavioral, 67, 175-181.

Ismail, M. N., N., Ngah, A., \& Umar, I. N. (2010). Instructional strategy in the teaching of computer programming: A need assessment analyses. TOJET: The Turkish Online Journal of Educational Technology,9(2).125-131.

Kim, D.(2017). The impact of learning management systems on academic performance: Virtual competency and student involvement. Journal of Higher Education Theory and Practice, 17(2). 23-35.

Kutner, H. M., Li, W., Neter, J., \& Nachtsheim, J. C. (2005). Applied Linear Statistical Model (5 ed.). Mc Graw Hill Education.

Lim, D. H., \& Morris, M. L. (2009). Learner and instructional factors influencing learning outcomes within a blended learning environment. Educational Technology \& Society, 12(4), 282-293.

Mabni, Z., Shamsudin, N., Aliman, S., \& Abd Latif, R. (2018). The effects of blended learning approach on student performance in the first computer programming course: A case study at UiTM, International Journal on e-Learning and Higher Education (IJELHE), Vol. 8, Jan 2018, 81 - 93.

Mayes, J.T., and C.J. Fowler (1999). Learning technology and usability: a framework for understanding courseware. Interacting with Computers, $11(5)$, $485-497$.

Mestan, K. (2019). Create a fine blend: An examination of institutional transition to blended learning. Australasian Journal of Educational Technology, 35(1),70-84.

Owston, R., Wideman, H., Murphy, J., \& Lupshenyuk, D. (2008). Blended teacher professional development: A synthesis of three program evaluations. The Internet and Higher Education, 11(3-4), 201-210.

Poon, J. (2013). Blended learning: An institutional approach for enhancing students' learning experiences. Journal of Online Learning and Teaching, 9(2), 271-288.

Ramakrisnan, P., Yahya, Y., Jono, M., N., H., H., \& Abdul Aziz, A. (2012). Blended Learning: A suitable framework for E-Learning in higher education. Procedia - Social Science and Behavioral, 67, 513-526.

Roberts, G. (2003). Teaching using the web: conceptions and approaches from a phenomenographic perspective. Instructional Science, 31, $127-150$.

Salem, S. F., and Salem, S. O. (2015). Factors influencing the learning management system (LMS) success among undergraduate students in Limkokwing University of Creative Technology, Malaysia. International Journal of Multicultural and Multireligious Understanding, 2(3), 17-26.

Schwenger, B. (2016). Enhancing students' tertiary blended learning experience through embedding digital information literacy. Journal of Perspectives in Applied Academic Practice, 4(1), 71-77.

Shamsudin, N., Abdullah, M. H., Abd Aziz, Z., \& Mohammad, N. (2018). Attributes contributing to algorithmic-problem solving competencies: Advanced Science Letters Journal, 24(10), October 2018, 7324-7332 (5)

Sharpe, R., Benfield, G., Roberts, G., \& Francis, R. (2006). The undergraduate experience of blended e-learning: A review of UK literature and practice. York, UK: The Higher Education Academy. 103 pages.

Twigg, C. A. (2004). Improving learning and reducing costs: Lessons learned from Round 1 of the Pew grant program in course redesign. Troy, NY: Center for Academic Transformation. 1-10.

Vaughan, N. (2014). Student engagement and blended learning: Making the assessment connection. Education Science, 4, 247-264

Za'ba, N., Mamat, M., Mohd Isa, M. A., Aziz, A., Ramakrisnan, P., \& Mat Zain, N., H. (2012). A comparative study among selected global standards: i-Learn as a case study. Procedia - Social and Behavioral Sciences. 67. 476-483. 